\title{
BUTTERFLY COMMUNITY STRUCTURE AND DIVERSITY IN SANGIHE ISLANDS, NORTH SULAWESI, INDONESIA
}

\author{
KONERI, R. ${ }^{*}-$ NANGOY, M.-J. ${ }^{2}$ \\ ${ }^{1}$ Department of Biology, Sam Ratulangi University \\ Campus Sam Ratulangi University Street, Bahu, Manado, North Sulawesi 95115, Indonesia \\ (phone: +62-813-4027-5276) \\ ${ }^{2}$ Department of Animal Production, Sam Ratulangi University \\ Campus Sam Ratulangi University Street, Bahu, Manado, North Sulawesi 95115, Indonesia \\ (phone: +62-812-4239-9445) \\ *Corresponding author \\ e-mail: ronicaniago@unsrat.ac.id \\ (Received $3^{\text {rd }}$ Nov 2018; accepted $28^{\text {th }}$ Jan 2019)
}

\begin{abstract}
Butterflies have an important role in the ecosystem of Sangihe Island, North Sulawesi, Indonesia. Currently, data on the diversity of butterflies on the island are still lacking and have not been published yet. Therefore, this study was aimed to analyze the structure of the butterfly community and its diversity in Sangihe Island, North Sulawesi, Indonesia. The research was conducted from March 2018 to May 2018 in Sangihe Island, North Sulawesi. Sampling was performed at three types of habitat: a farm, a forest edge, and bushes. Sampling method used was surveyed with purposive sampling. A collection of butterflies was gathered by the sweeping method using sweep net following the transect line randomly for $500 \mathrm{~m}$ long. At each habitat, four transects were set and the collection step was duplicated. Sampling was performed from $8.00 \mathrm{am}$ to $15.00 \mathrm{pm}$. The collection comprised of 5 families, 39 species, and 944 individuals. The most commonly found family was Nymphalidae, while the most abundant species were Junonia hedonia intermedia and Eurema tominia. Species abundance, species richness index, species diversity index, and species evenness index were found to be the highest at the forest edge habitat, while the lowest ones were from the bushes. The diversity of the butterflies at the forest edge habitat was higher since host plants were located in the area, and the vegetation served as a food source and shelter for the animals.
\end{abstract}

Keywords: forest edge, sweep net, Junonia hedonia, Nymphalidae, host plant

\section{Introduction}

Sangihe Island is one of the most remote islands in the province of North Sulawesi, which directly borders with the Philippines. The Sangihe Island biodiversity involves a variety of plants and animals including butterflies (Shekelle et al., 2008; Central Agency on Statistics, 2015).

Butterflies are part of Lepidoptera, a type of insect with scaled wings. The scales provide beautiful colour patterns such as ribbon, nodes, and circles (Braby, 2004; Arya et al., 2014). The beautiful color patterns make several types of butterflies highly hunted and traded as collection, thus making them declared as endangered species (Coote, 2000). The diversity of butterflies in Indonesia is abundant, which consists of about 1,600 species out of 20,000 species among all species of butterflies worldwide (Alarape et al., 2015). The rich biodiversity in Indonesia could only be rivalled by the tropical countries in South America, such as Brazil and Peru that have about 3,000 species. The king butterfly, Troides hypolitus, is mostly found in the western part of Indonesia and Sulawesi, with some species spread in Maluku and Papua. Sulawesi is an island with the highest uniqueness of butterflies in Indonesia. From 557 species of butterflies spread in 
Sulawesi, 239 of them (more than 40\%) are endemic and can only be found on the island, such as Papilio blumei. Meanwhile, more than 600 species are spread in Java and Bali islands, $40 \%$ of which are endemic species (Amir and Kahono, 2008; Nidup et al., 2014).

Butterflies have an important role in maintaining the biodiversity with their function as pollinator that help pollination in plants, thus they help breeding of plants naturally (Plona, 2002; Perveen and Haroon, 2015). Moreover, butterflies are an important food for birds, reptiles, spiders and other predatory insects (Haroon et al., 2013). In terms of conservation of the ecosystem, butterflies are popular as bioindicators of the change of quality of the environment (Patil and Shende, 2014; Arya et al., 2014; Ghosh and Mukherjee, 2016).

Butterflies are often used as a model by scientists to estimate and predict biodiversity due to the effect of local and global climate change, environmental damage, distribution of plants and animals, forest management on the natural ecosystem (Axmacher et al., 2004; Vu et al., 2015). Several research studies have shown that deforestation in tropical countries due to illegal logging, over volume of logging, and clearing of forest area to provide space for farms, all could affect the distribution, structure, and composition of the community, diversity of the species of butterflies (Van Vul and Quang Vu, 2011; Nidup et al., 2014; Widhiono, 2015; Vu et al., 2015; Nkongolo and Bapeamoni, 2018). Butterflies are also affected by environmental variations and changes in the forest structure; moreover, they are also affected by the abundance of plants they feed on (Bora and Meitei, 2014; Castro and Espinosa, 2015). Butterflies are also highly sensitive to climate change (Parmesan and Yohe, 2003). Therefore this study was aimed to analyze the community structure and biodiversity of butterflies at Sangihe Island, North Sulawesi, Indonesia.

\section{Materials and methods}

\section{Study area and types of land use}

The study was performed from March to May 2018 at Sangihe Island, North Sulawesi, Indonesia (Fig. 1). Sampling was done on 3 types of habitat: forest edge, farming area, and bushes. In each habitat, 4 transect lines of $500 \mathrm{~m}$ were laid out. On each transect, air temperature, air humidity, canopy closure, altitude, and coordinates, were measured. Measurement of air temperature and humidity was carried out using Thermo-Hygrometer while taking of butterfly samples. The percentage of canopy coverage in each habitat was obtained by making a plot of $20 \mathrm{~m}$ x $20 \mathrm{~m}$ on each transect so that there were 4 plots in each habitat type. The percentage of canopy coverage in each plot was obtained by vertically projecting tree canopy coverage on the plot. Vertical projection on the flat area of the land was then converted into percentage, with the area of the plot as a denominator, so that the value of canopy coverage will be obtained for each plot in each transect. Altitude and coordinates were measured using a Global Positioning System (GPS) on each transect line.

The forest edge is a habitat that contains variety of plants such as Ficus sp (Moraceae), Alstonia macrophylla (Apocynaceae) and Garcinia sp. (Clusiaceae). At this habitat, there was a river with $8-10 \mathrm{~m}$ width. The area had a daily temperature ranging from $28.1-29.9^{\circ} \mathrm{C}$, the humidity of $82-87$, canopy coverage of $76-86 \%$, the altitude of $120-201 \mathrm{~m}$ above sea level, and it is located at the following coordinates $03^{\circ} 30^{\prime} 05.56^{\prime \prime} \mathrm{S}$ and $125^{\circ} 31^{\prime} 43.31^{\prime \prime} \mathrm{E}$. 


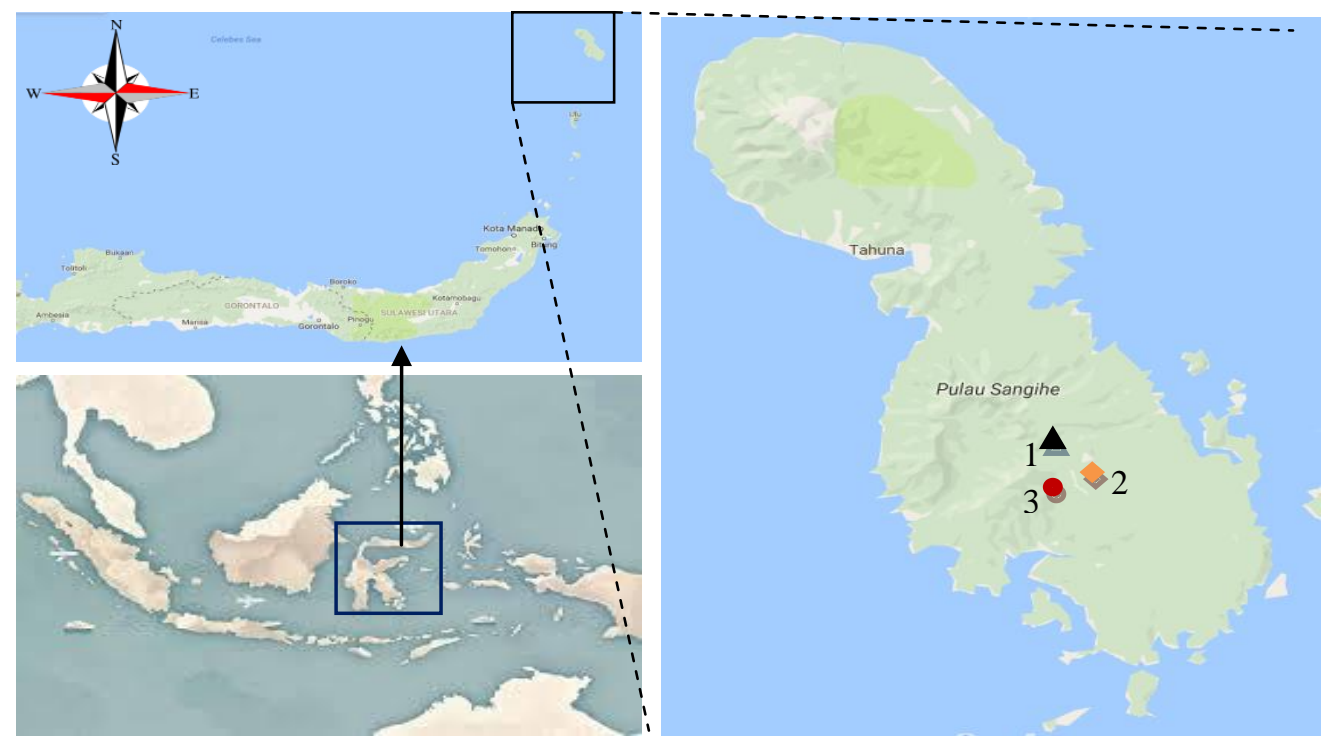

Figure 1. Map of the study area in Sangihe Islands, North Sulawesi, Indonesia (1. edge forest, 2. farm area, 3. bushes)

The farm area is an area managed by the local community and planted with a variety of crops such as cloves (Eugenia aromatica), coconut (Cocos nucifera), banana (Musa sp) and cassava (Manihot utilisima). The farming area selected in this study had a daily temperature of $29.2-30.3{ }^{\circ} \mathrm{C}$, the humidity level of $79-82$, canopy coverage of $70-80 \%$, the altitude of $61-97 \mathrm{~m}$ above sea level, and it is located at the following coordinates $03^{\circ} 26^{\prime} 21.27^{\prime \prime} \mathrm{S}$ and $125^{\circ} 36^{\prime} 01.77^{\prime \prime} \mathrm{E}$.

The bushes area selected in this study was formerly a farming area that has been abandoned by the local community and covered with plants such as ferns (Pteridophyta), grass (Poaceae), and bamboo (Bambusa sp). This habitat had a daily temperature of $33.0-35.3{ }^{\circ} \mathrm{C}$, the humidity of $51-65$, canopy coverage of $40-57 \%$, the altitude of $120-137 \mathrm{~m}$ above sea level, and it is located at the coordinates of $03^{\circ} 26^{\prime} 52.73^{\prime \prime} \mathrm{S}$ and $125^{\circ} 35^{\prime} 42.28^{\prime \prime} \mathrm{E}$ (Fig. 2).

\section{Sampling}

Research method used was survey method through purposive sampling. Butterflies were collected with a sweeping method by using a net following transect lines that were set randomly for $500 \mathrm{~m}$ length and $5 \mathrm{~m}$ width to each side, left and right (Hamer et al., 2003). At each habitat, four transects were prepared and at each transect, sampling was duplicated. The total number of transects was 12. Sampling was performed at 8 am-3 pm (Peggie and Amir, 2006). From every species, only one butterfly was collected. When similar species was found, it was released back to nature. Sampling was performed every month for 3 months. Sampling was done monthly for three months. Butterfly sampling for 3 months was quite representative and can provide information about the diversity of butterflies in the Sangihe Islands. This is because those three months were during the dry season when the weather conditions were sunny. Those conditions were very suitable for butterflies to live. During this period, most nectar-rich plants began to flower (Rizal, 2007), thus providing butterflies food sources and supporting the life and breeding of butterflies. 

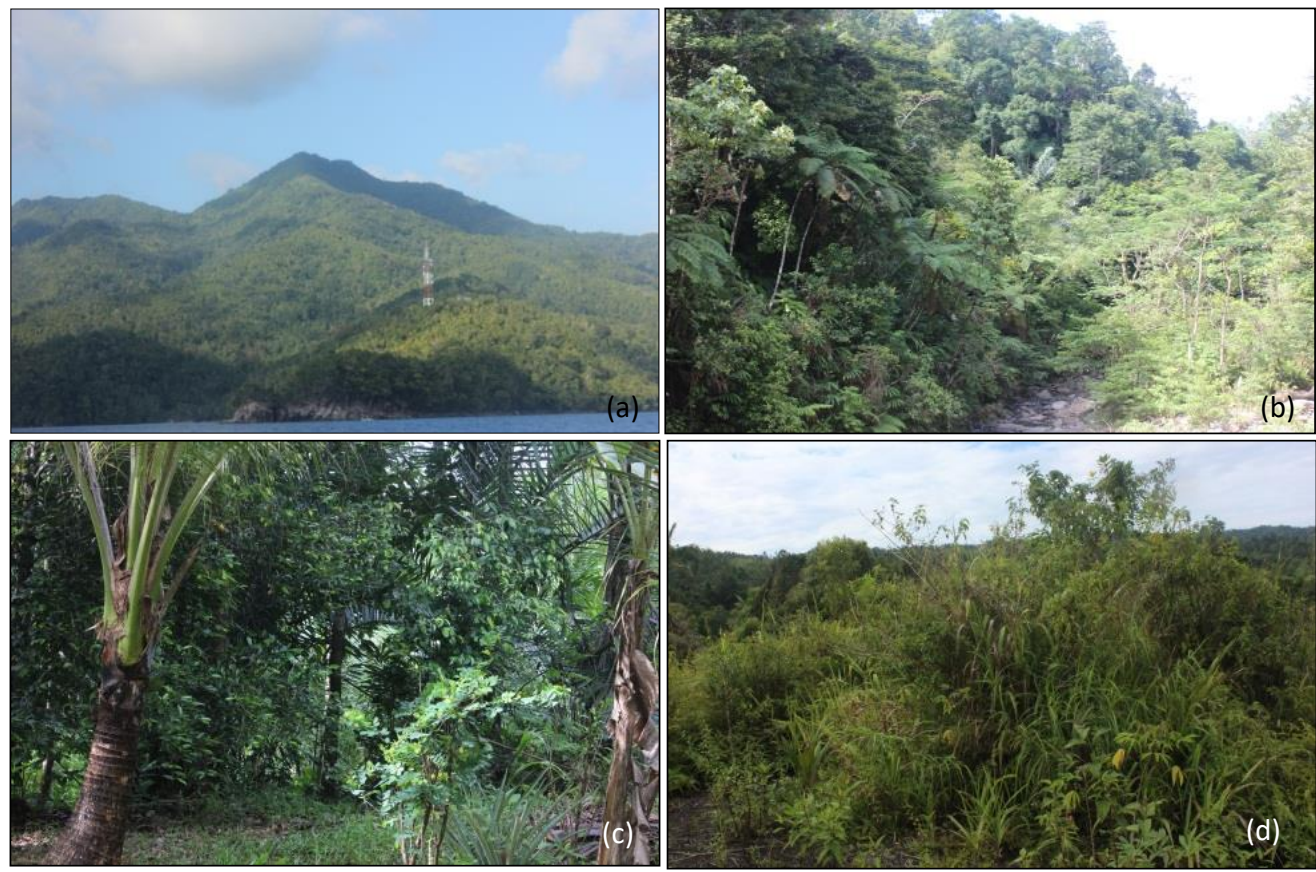

Figure 2. Photographs of study sites (a) Sangihe Island, (b) edge forest, (c) farm area, (d) bushes

\section{Identification of butterfly samples}

The process of identifying and classifying the specimens was based on the following identification books: Practical Guide to the Butterflies of Bogor Botanic Garden (Peggie and Amir, 2006), Agricultural entomology (Jumar, 2000), Butterflies of The South East Asian Island, Part I Papilionidae, Part II Pieridae-Danaidae, Part III SatyridaeLybytheidae, Part IV Nymphalidae (I), Part V Nymphalidae (II) (Tsukada and Nishiyama, 1982, 1981,1982,1985, 1991), and Insect in Halimun Mountain National Park Bagian Barat (Amir et al., 2003).

\section{Data analysis}

Data analysis in this study was performed on several parameters: species abundance $(\mathrm{n})$, species richness index $(\mathrm{S})$, species diversity index $(\mathrm{H})$ and species evenness index (E). Species abundance is the number of individual in each species found in each habitat. At all habitats, the indices used were Margalef species richness index (DMg), Shannon species diversity index $(\mathrm{H})$ and Pielou species evenness index (J) (Magurran, 1988).

Species richness index (Dmg) was calculated using Margalefs index to show the number of species in a certain type of habitat (Magurran, 1988), using Equation 1:

$$
\text { Species richness Indeks }(\mathrm{Dmg})=\frac{(\mathrm{s}-1)}{\ln \mathrm{S}}
$$

where: $S=$ The number of species.; $l n=$ Natural logarithm (natural number). 
Meanwhile, species diversity index was calculated using the Shannon-Weiner diversity index $(\mathrm{H})$ in Magurran (1988) to describe the diversity of butterfly species, using Equation 2:

$$
\text { Spesies diversity index }\left(\mathrm{H}^{\prime}\right)=-\sum_{i=l}^{s}(\mathrm{Pi}) \ln (\mathrm{Pi})
$$

where: $\mathrm{Pi}=$ the proportion of each species; $\mathrm{ln}=$ natural logarithm (natural number).

At the same time, to show the level of evenness of individual abundance in each butterfly species and as an indicator of species dominance in each habitat, species evenness index was calculated using Pielou's evenness index (Magurran, 1988), using Equation 3:

$$
\text { Species evenness index }(\mathrm{E})=\frac{H^{n}}{\operatorname{Ln} S}
$$

where: $H^{\prime}=$ species diversity index; $\mathrm{ln}=$ natural logarithm (natural number); $S=$ the number of species.

All indexes were calculated with the help of the program PAST 2.17 (Hammer et al., 2001). Statistical analysis to analyze the difference in species abundance, species richness index, and species evenness index among habitats was performed using the software Statistica version 6, with one-way ANOVA and Duncan test at a confidence level of 95\% (StatSoft, 2001; Ohsawa, 2005). To check the relationship between species diversity with other physicochemical parameters in nature, the Spearman correlation was used using the software Statistica version 6 (StatSoft, 2001).

Analysis of similarity between butterfly communities was performed with Sorensen similarity index, by checking the existence and inexistence of certain species of butterfly (Magguran, 1988). The index was calculated using Biodiv 97, macro software in Excel (Shahabuddin et al., 2005). Index of dissimilarity (1 - Sorensen index) was used to do cluster analysis (Krebs, 1999; Ludwig and Reynold, 1988). Cluster analysis of every community was ordered hierarchal in the form of a dendrogram. The dendrogram was prepared using the program Statistica for Windows 6 (StatSoft, 2001). The clustering process was based on unweighted pair group with arithmetic mean and Euclidian distance (Lewis, 2001).

\section{Results}

\section{Structure and composition of butterflies}

The results found 5 families of butterflies in Sangihe Island, consisting of 39 species and 944 individuals. The families found were Nymphalidae, Papilionidae, Lycaenidae, Pieridae, and Hesperidae. The family with the highest number of species and individuals was Nymphalidae, with 19 species and 508 individuals (53.81\%), followed by the family Papilionidae with 8 species and 214 individuals $(22.67 \%)$. The family Nymphalidae was the most dominant family that was found in all sampling areas. Meanwhile, Hesperidae was the family with the least number of species, with only 2 species and 5 individuals $(0.64 \%)$. The family Hesperidae was only found at the forest edge and farm and not in the bushes (Table 1 and Fig. 3). 
Table 1. Number of families, species, and individuals found in three types of Habitat in Sangihe Island, North Sulawesi

\begin{tabular}{|c|c|c|c|c|c|c|}
\hline \multirow[t]{2}{*}{ No } & \multirow[t]{2}{*}{ Family/Species } & \multicolumn{3}{|c|}{ Number of Individuals } & \multirow{2}{*}{$\begin{array}{c}\text { Grand } \\
\text { Total } \\
\end{array}$} & \multirow[t]{2}{*}{$\%$} \\
\hline & & Faram & Bushes & Edge Forest & & \\
\hline $\mathbf{I}$ & Nymphalidae & & & & & \\
\hline 1 & Junonia hedonia intermedia & 58 & 73 & 64 & 195 & 20.66 \\
\hline 2 & Cupha arias & 16 & 8 & 19 & 43 & 4.56 \\
\hline 3 & Danaus affinitis fulgarata & 23 & 7 & 6 & 36 & 3.81 \\
\hline 4 & Euploea leucostictos westwodi & 3 & 8 & 21 & 32 & 3.39 \\
\hline 5 & Danaus genutia leucoglene & 12 & 0 & 11 & 23 & 2.44 \\
\hline 6 & Hypolimnas bolina & 2 & 0 & 20 & 22 & 2.33 \\
\hline 7 & Lasippa neriphus tawayana & 9 & 0 & 11 & 20 & 2.12 \\
\hline 8 & Danaus ismare alba & 1 & 15 & 3 & 19 & 2.01 \\
\hline 9 & Melanitis leda obsolete & 13 & 3 & 2 & 18 & 1.91 \\
\hline 10 & Parthenos sylva salentia & 2 & 0 & 14 & 16 & 1.69 \\
\hline 11 & Idea leuconoe & 4 & 3 & 8 & 15 & 1.59 \\
\hline 12 & Mycalesis janardana & 3 & 7 & 5 & 15 & 1.59 \\
\hline 13 & Orsotriaena medus & 14 & 0 & 1 & 15 & 1.59 \\
\hline 14 & Ideopsis juventa tontoliensis & 8 & 1 & 4 & 13 & 1.38 \\
\hline 15 & Lohara optalmica & 6 & 3 & 2 & 11 & 1.17 \\
\hline 16 & Mycalesis horsfieldi & 5 & 0 & 2 & 7 & 0.74 \\
\hline 17 & Terinos clarisssa & 0 & 0 & 5 & 5 & 0.53 \\
\hline 18 & Faunis manado & 2 & 0 & 0 & 2 & 0.21 \\
\hline 19 & Cyrestis acilia & 0 & 0 & 1 & 1 & 0.11 \\
\hline II & Papilionidae & & & & & \\
\hline 20 & Graphium meyeri & 28 & 8 & 36 & 72 & 7.63 \\
\hline 21 & Papilio rumanzovia & 3 & 25 & 34 & 62 & 6.57 \\
\hline 22 & Papilio polytes & 7 & 22 & 10 & 39 & 4.13 \\
\hline 23 & Papilio sataspes & 0 & 0 & 14 & 14 & 1.48 \\
\hline 24 & Graphium milon & 6 & 0 & 5 & 11 & 1.17 \\
\hline 25 & Graphium agamemnon & 0 & 5 & 3 & 8 & 0.85 \\
\hline 26 & Papilio gigon & 2 & 0 & 3 & 5 & 0.53 \\
\hline 27 & Papilio helenus & 0 & 3 & 0 & 3 & 0.32 \\
\hline III & Lycaenidae & & & & & \\
\hline 28 & Pithecops phoenix & 20 & 0 & 9 & 29 & 3.07 \\
\hline 29 & Jamides aratus & 4 & 0 & 22 & 26 & 2.75 \\
\hline 30 & Jamides celeno & 2 & 1 & 3 & 6 & 0.64 \\
\hline 31 & Lampides boeticus & 0 & 0 & 5 & 5 & 0.53 \\
\hline 32 & Rapala ribbei & 3 & 0 & 0 & 3 & 0.32 \\
\hline IV & Pieridae & & & & & \\
\hline 33 & Eurema tomina & 21 & 19 & 38 & 78 & 8.26 \\
\hline 34 & Eurema blanda & 8 & 11 & 12 & 31 & 3.28 \\
\hline 35 & Eurema hecabe & 5 & 6 & 18 & 29 & 3.07 \\
\hline 36 & Catopsilia pamona flava & 0 & 2 & 7 & 9 & 0.95 \\
\hline 37 & Gandaca blanda & 0 & 0 & 9 & 0 & 0.00 \\
\hline $\mathbf{V}$ & Hesperidae & & & & & \\
\hline 38 & Borbo cinnara & 4 & 0 & 0 & 4 & 0.42 \\
\hline 39 & Erionota thrak & 0 & 0 & 2 & 2 & 0.21 \\
\hline & Total & 294 & 230 & 420 & 944 & 100.00 \\
\hline
\end{tabular}



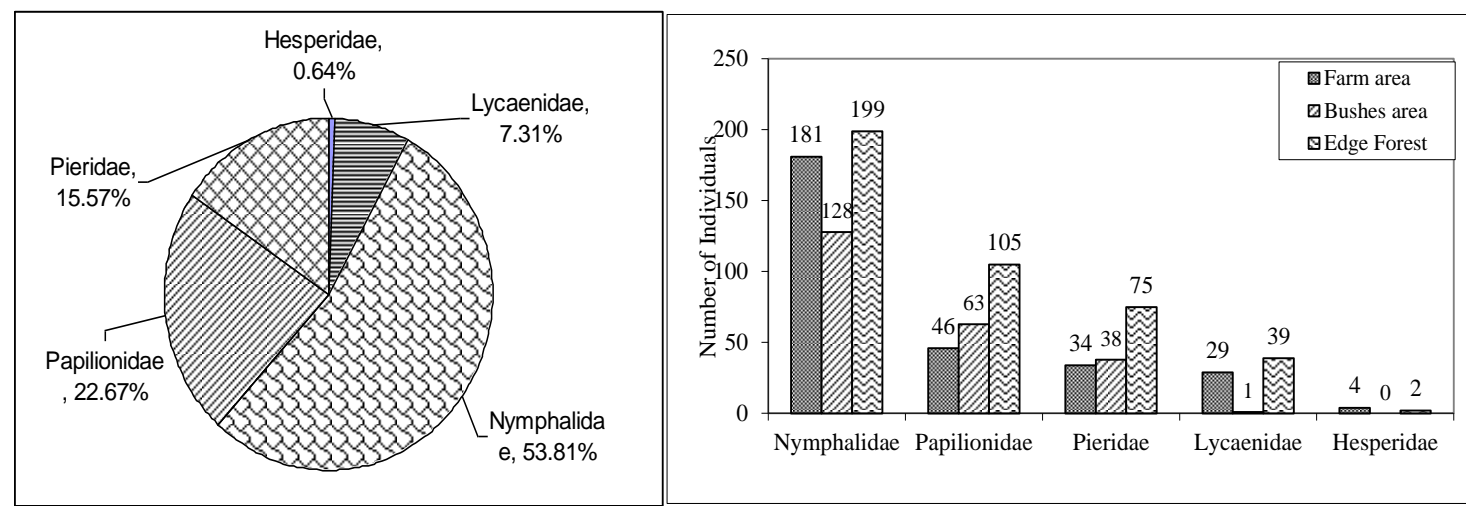

Figure 3. The abundance of family butterflies found in three types of habitat at Sangihe Island, North Sulawesi

Junonia hedonia intermedia is a butterfly species with the highest abundance (20.66\%) compared to other species, followed by Eurema tominia with the abundance of $8.26 \%$. Butterfly species with the lowest abundance with only 1 individual $(0.11 \%)$ was Cyrestis acilia (Table 1 and Fig. 4).

The species of butterflies found in all three habitats were not similar. There were species that were found in all 3 habitats, some were found only in 2 habitats, and some others were found only in 1 habitat. There were 17 species found in all types of habitat and 12 species found in only 2 habitats. Meanwhile, 3 species were found only in farm area while Papilio helenus was found only in the bushes. The species found only in the forest edge habitat were 6 species (Table 1).
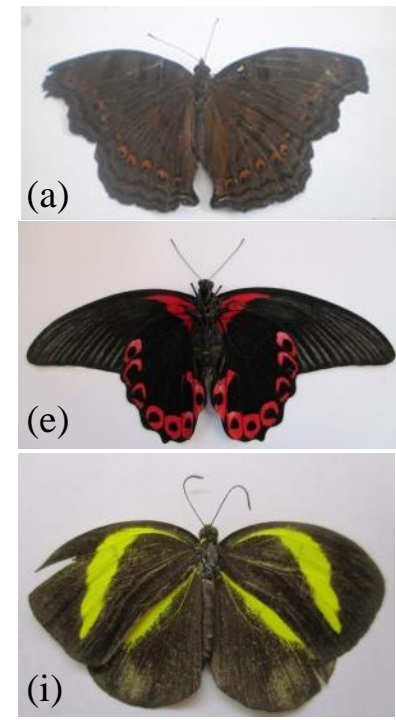
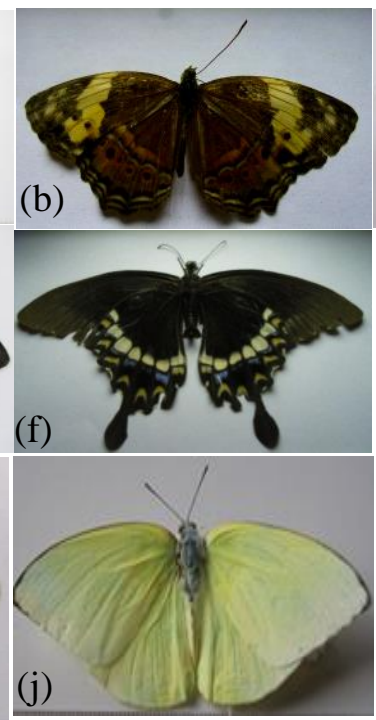
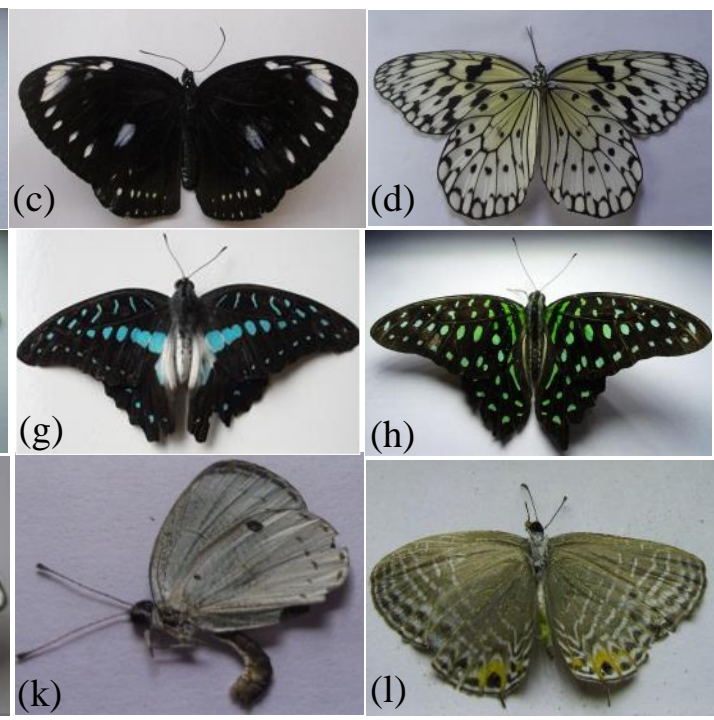

(c)
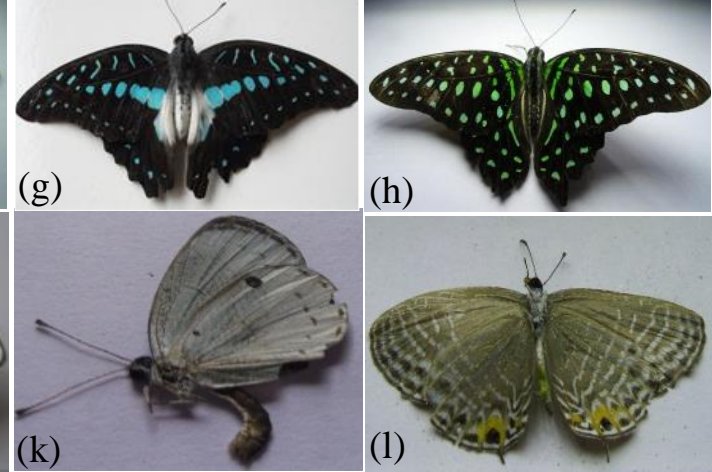

Figure 4. Several species of butterflies found in the Sangihe Islands. Families Nymphalidae: (a) Brown pansy (J. hedonia intermedia), (b) Heliconians (C. arias), (c)

Westwood's king crow (E. leucostictos westwoodi), (d) Paper kite (I. leuconoe);

Papilionidae: (e) Red Mormon (P. rumanzovia), $(f)$ Common Mormon (P. polytes), $(g)$ Meyer's Triangle (G. meyeri), (h) Tailed jay (G. agamemnon); Pieridae: (i) Grass yellows (E. tominia), (j) Lemon Emigrant (C. pamona flava); Lycaenidae; $(k)$ Sulawesi Quaker (P. phoenix), and (l) Common Cerulean (J. celeno) 


\section{Butterfly species diversity}

The average value of species abundance $(118.00 \pm 33.46)$, species richness index $(4.52 \pm 0.48)$, species diversity index $(2.82 \pm 0.14)$ and species evenness index $(0.91 \pm 0.02)$ were found to be the highest at forest edge habitat, while the lowest one was found in the bushes habitat (Table 2; Fig. 5). One-way ANOVA and Duncan tests showed that there were significant differences in terms of richness index (ANOVA: $\mathrm{F}=15.72 ; \mathrm{P}<0.05$ ), and diversity index of species (ANOVA: $\mathrm{F}=32.96 ; \mathrm{P}<0.05$ ), among habitats, while abundance (ANOVA: $\mathrm{F}=4.05$; $\mathrm{P}>0.05$ ) and evenness indices (ANOVA: $\mathrm{F}=2.04 ; \mathrm{P}>0.05$ ), were not significantly different. The species richness index and species diversity index of butterflies found in the farm were significantly different with those found in the forest edge and bushes habitats (Table 2; Fig. 5).

Table 2. Species diversity of butterflies in three types of habitat at Sangihe Island, North Sulawesi (Average \pm St dev)

\begin{tabular}{|c|c|c|c|c|c|}
\hline Habitat & Transect & $\begin{array}{c}\text { Abundance } \\
\text { species }\end{array}$ & $\begin{array}{c}\text { Richness } \\
\text { index }\end{array}$ & $\begin{array}{l}\text { Diversity } \\
\text { index }\end{array}$ & $\begin{array}{c}\text { Evenness } \\
\text { index }\end{array}$ \\
\hline Farm area & 1 & 106 & 4.50 & 2.72 & 0.88 \\
\hline Farm area & 2 & 60 & 3.18 & 2.35 & 0.89 \\
\hline Farm area & 3 & 44 & 3.44 & 2.35 & 0.89 \\
\hline Farm area & 4 & 92 & 3.54 & 2.51 & 0.89 \\
\hline Average \pm St dev & & $75.50 \pm 24,67$ & $3.66 \pm 0.50$ & $2.48 \pm 0.15$ & $0.89 \pm 0.01$ \\
\hline Forest edge & 1 & 100 & 4.13 & 2.71 & 0.91 \\
\hline Forest edge & 2 & 141 & 5.05 & 3.02 & 0.93 \\
\hline Forest edge & 3 & 158 & 4.94 & 2.88 & 0.88 \\
\hline Forest edge & 4 & 73 & 3.96 & 2.66 & 0.92 \\
\hline Average \pm St dev & & $118.00 \pm 33.46$ & $4.52 \pm 0.48$ & $2.82 \pm 0.14$ & $0.91 \pm 0.02$ \\
\hline Bushes area & 1 & 42 & 2.14 & 1.92 & 0.88 \\
\hline Bushes area & 2 & 44 & 2.91 & 1.90 & 0.76 \\
\hline Bushes area & 3 & 87 & 2.69 & 2.04 & 0.80 \\
\hline Bushes area & 4 & 63 & 1.93 & 2.06 & 0.94 \\
\hline Average \pm St dev & & $59.00 \pm 18.12$ & $2.42 \pm 0.40$ & $1.98 \pm 0.07$ & $0.84 \pm 0.07$ \\
\hline
\end{tabular}

\section{Correlation between species diversity and environmental factors}

The results of temperature measurements in farm area habitat showed an average value and standard deviation of $29.68{ }^{\circ} \mathrm{C} \pm 0.40$, edge of forest showed an average value and standard deviation of $28.58{ }^{\circ} \mathrm{C} \pm 0.77$, and bushes habitat showed an average value and standard deviation of $34.20^{\circ} \mathrm{C} \pm 0.83$. Average air humidity on farm area was $80.70 \% \pm$ 1.09 , on edge of the forest was $83.50 \% \pm 1.12$, and bushes habitat was $57.75 \% \pm 5.26$. Canopy coverage on farm area was averagely $74.75 \% \pm 3.56$, on edge of the forest was averagely $81.75 \% \pm 4.02$, and on bushes habitat was averagely $48.00 \% \pm 6.28$ (Table 3 ).

Correlation between the diversity of butterfly species with the environmental factors showed that temperature was negatively correlated with species diversity index $(-0.85)$ and species richness index (-0.77) (Table 4). This result shows that the lower the temperature, thus the higher the species diversity and species richness indices of butterflies. Species richness index and species diversity index of butterflies were 
positively correlated with humidity and canopy coverage percentage. Meanwhile, the altitude did not give significant effect on species diversity of butterflies.
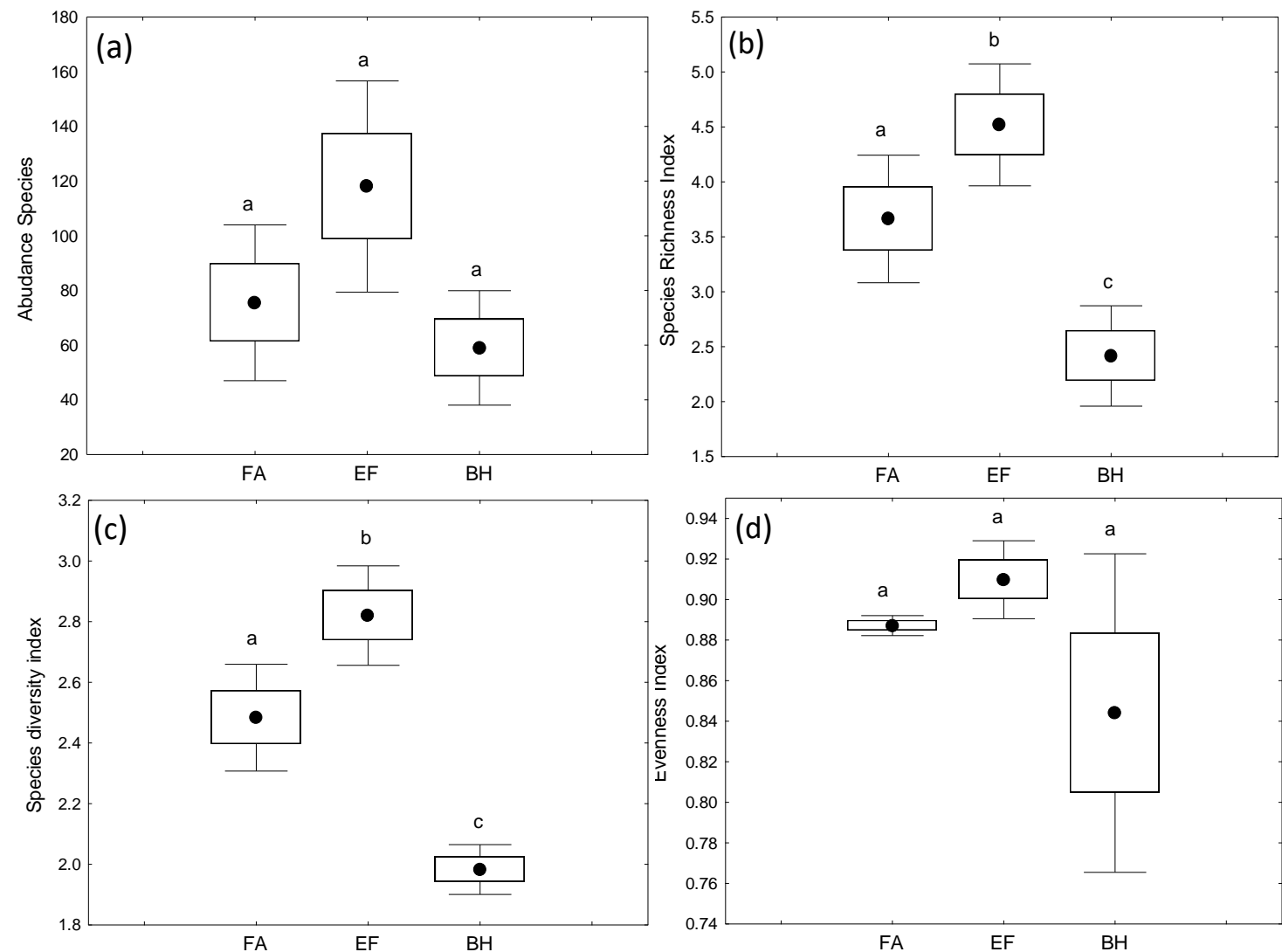

Figure 5. The influence of habitat types on (a) abundance, (b) richness (c) diversity and $(d)$ evenness species index in Sangihe Islands, North Sulawesi. (FA: farm area; EF: an edge of the

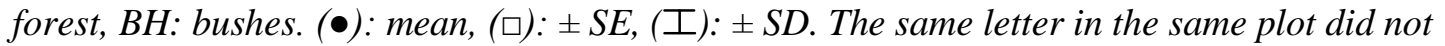
differ significantly according to Duncan's test at $95 \%$ confidence level)

Table 3. Species diversity butterflies and environmental factor in three types of habitat at Sangihe Island, North Sulawesi

\begin{tabular}{l|c|c|c|c|c|c|c|c|c}
\hline \multirow{2}{*}{ Habitat } & \multirow{2}{*}{ Transect } & \multicolumn{4}{|c|}{ Species diversity } & \multicolumn{4}{c}{ Environmental factors } \\
\cline { 3 - 10 } & & $\begin{array}{c}\text { Abudance } \\
\text { Species }\end{array}$ & $\begin{array}{c}\text { Richness } \\
\text { index }\end{array}$ & $\begin{array}{c}\text { Diversity } \\
\text { Index }\end{array}$ & $\begin{array}{c}\text { Evennes } \\
\text { index }\end{array}$ & $\begin{array}{c}\text { Temperature } \\
(\mathbf{0 C})\end{array}$ & $\begin{array}{c}\text { Humidity } \\
(\boldsymbol{\%})\end{array}$ & $\begin{array}{c}\text { Canopy } \\
(\boldsymbol{\%})\end{array}$ & $\begin{array}{c}\text { Altitude } \\
(\mathbf{M} \text { asl) }\end{array}$ \\
\hline Farm area & 1 & 106 & 4.50 & 2.72 & 0.88 & 29.7 & 79 & 70.00 & 77 \\
Farm area & 2 & 60 & 3.18 & 2.35 & 0.89 & 29.5 & 82 & 75.00 & 95 \\
Farm area & 3 & 44 & 3.44 & 2.35 & 0.89 & 29.2 & 81 & 80.00 & 61 \\
Farm area & 4 & 92 & 3.54 & 2.51 & 0.89 & 30.3 & 81 & 74.00 & 97 \\
\hline Average \pm Stdev & & $75.50 \pm 24,67$ & $3.66 \pm 0.50$ & $2.48 \pm 0.15$ & $0.89 \pm 0.01$ & $29.68 \pm 0.40$ & $80.75 \pm 1.09$ & $74.75 \pm 3.56$ & $82.5 \pm 14.65$ \\
\hline Forest edge & 1 & 100 & 4.13 & 2.71 & 0.91 & 28.1 & 83 & 86.00 & 120 \\
Forest edge & 2 & 141 & 5.05 & 3.02 & 0.93 & 29.9 & 82 & 80.00 & 178 \\
Forest edge & 3 & 158 & 4.94 & 2.88 & 0.88 & 28.3 & 85 & 85.00 & 196 \\
Forest edge & 4 & 73 & 3.96 & 2.66 & 0.92 & 28.0 & 84 & 76.00 & 201 \\
\hline Average \pm Stdev & & $118.00 \pm 33.46$ & $4.52 \pm 0.48$ & $2.82 \pm 0.14$ & $0.91 \pm 0.02$ & $28.58 \pm 0.77$ & $83.50 \pm 1.12$ & $81.75 \pm 4.02$ & $173.75 \pm 32.19$ \\
\hline Bushes area & 1 & 42 & 2.14 & 1.92 & 0.88 & 35.3 & 51 & 50.00 & 130 \\
Bushes area & 2 & 44 & 2.91 & 1.90 & 0.76 & 34.0 & 60 & 40.00 & 137 \\
Bushes area & 3 & 87 & 2.69 & 2.04 & 0.80 & 34.5 & 55 & 45.00 & 125 \\
Bushes area & 4 & 63 & 1.93 & 2.06 & 0.94 & 33.0 & 65 & 57.00 & 120 \\
\hline Average \pm Stdev & & $59.00 \pm 18.12$ & $2.42 \pm 0.40$ & $1.98 \pm 0.07$ & $0.84 \pm 0.07$ & $34.20 \pm 0.83$ & $57.75 \pm 5.26$ & $48.00 \pm 6.28$ & $128.00 \pm 6.28$ \\
\hline
\end{tabular}


Table 4. Correlation coefficient among butterflies diversity and environmental factor

\begin{tabular}{c|c|c|c|c}
\hline Variable & Temperature & Humidity & Canopy & Altitude \\
\hline Abundance species & -0.49 & 0.53 & 0.55 & 0.47 \\
Richness index & $-0.77^{*}$ & $0.79^{*}$ & $0.75^{*}$ & 0.35 \\
Diversity Index & $-0.85^{*}$ & $0.86^{*}$ & $0.86^{*}$ & 0.34 \\
Evenness index & -0.57 & 0.57 & $0.70^{*}$ & 0.12 \\
\hline
\end{tabular}

*Marked correlations are significant at $\mathrm{p}<.05000, \mathrm{~N}=12$

\section{Community similarity}

Composition similarity of butterfly community in Sangihe Island showed that the highest similarity index was between the forest edge and farm habitats $(0.85$ or $85 \%)$. The lowest Sorensen similarity index was found between the forest edge and bushes habitats $(0.67$ or 67\%) (Table 5).

A dendrogram was produced using unweighted pair group method with arithmetic mean (UPGMA) and it shows that there were 2 groups formed, where forest edge habitat was grouped together with the farm habitat (Fig. 6). This result shows that the butterfly community at forest edge habitat was highly similar to that found in the farm habitat.

Table 5. Matrix about butterfly community similarity among habitats in Sangihe Island

\begin{tabular}{c|c|c|c}
\hline Habitat & Farm area & Edge forest & Bushes \\
\hline Farm area & 1.00 & 0.85 & 0.68 \\
Edge forest & 0.85 & 1.00 & 0.67 \\
Bushes & 0.68 & 0.67 & 1.00 \\
\hline
\end{tabular}

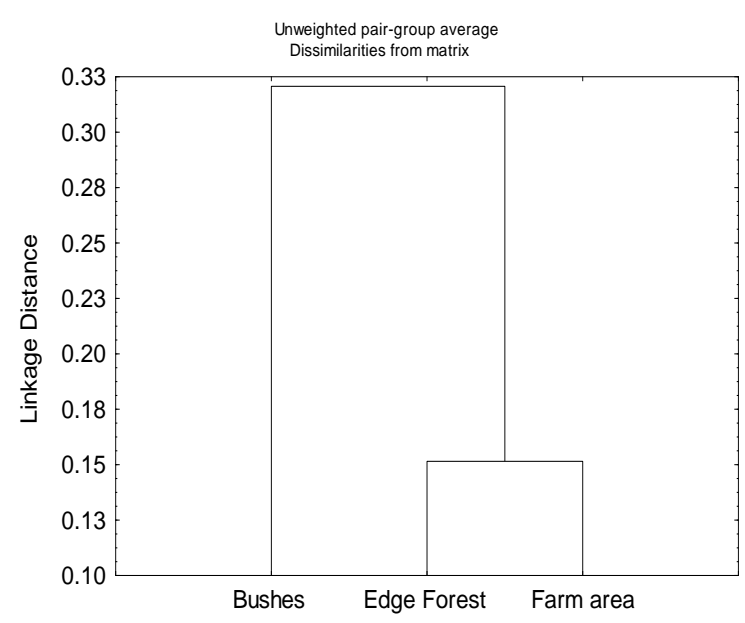

Figure 6. Dendrogram about butterfly community similarity among habitats in Sangihe Island

\section{Discussion}

The number of butterfly species found in the research was only $0.20 \%$ of all species worldwide, $2.23 \%$ of species found in Indonesia, and $6.96 \%$ of species found in Sulawesi. There are about 19,238 of butterfly species worldwide (Patil et al., 2017), 
1,750 species in Indonesia (Peggie, 2014), and 560 species in Sulawesi (Vane-Wright and de Jong, 2003). The number of butterfly species found in Sangihe Island in this study was lower than the results of several other studies carried out on the mainland of North Sulawesi. Studies in Manembo-Nembo Nature Reserve (Koneri and Maabuat, 2016) and Gunung Tumpa National Park (Tallei et al., 2015), North Sulawesi managed to find 44 and 50 species, respectively.

Several studies in other islands reported a higher number of butterfly species as compared to the current results found in Sangihe Island. Koneri and Saroyo (2012) reported 28 butterfly species in Manado Tua Island, Manado, North Sulawesi, while Lamatoa, et al. (2013) collected 19 species of butterfly in Mantehage Island, North Sulawesi. Moreover, Rosmidi et al. (2017) reported 27 butterfly species found in Perhentian Island and Bidong Island, Terengganu, Malaysia. The difference in the number of species found in each sampling location is affected by sampling area, sampling time, sampling method, habitat's condition and sampling period. The difference in the number of species between an island and the mainland is affected by the island area and distance between the island and the mainland. This result is in accordance with the biogeography theory of islands that mentions small and far islands support a lower number of species compared to bigger and nearer islands (Sumarto and Siahaan, 2012).

The family Nymphalidae was found abundantly in the study since it is a type of butterfly family that can adapt well to environmental conditions, has a large number of family members, and tend to be polyfag. The polyfag characteristic allows Nymphalidae to fulfill its need on host plant although the plant is not available. These reasons cause Nymphalidae exist in a relatively high number of species and individuals in Sangihe Island. According to Rosmidi et al. (2017), this phenomenon could be due to a large number of species in the family as well as their wide variety of selection of food, including flowers, fruits, honeydew, tree sap, rotten materials, and decomposing carcasses; moreover, they also have good adaptation on feeding on a wide range of host plants.

The host plants of Nymphalidae butterflies include Annonaceae, Asteraceae, Verbenaceae, Moraceae, Rubiaceae and Anacardiaceae (Lamatoa, et al., 2013). Plant species that are often found in Sangihe Island include Ficus sp (Moraceae), Mussaenda pubescens (Rubiaceae), Garcinia sp (Clusiaceae), Lantana camara (Verbenaceae), Cananga odorata (Annonaceae), Mangifera indica (Anacardiaceae), Ficus benjamina (Moraceae), Citrus sp (Rutaceae) and Eupatorium inulifolium (Asteraceae). A distinct difference in terms of the dominant family found in several places is due to the fact that distribution of butterflies is affected by the distribution of the host plant and the ecology (Amir et al., 2003; Panjaitan, 2008). The family Nymphalidae could be found easily all year since they are generalist and some types of this family do not depend only on the availability of flower nectar since they could get their food from rotten fruits or even animal urine (Sarma et al., 2012; Sari et al., 2013).

The species Junonia hedonia intermedia was found the most in the study. This species has wings with dark brown colour and orange eye pattern near the edge of the wings. It is able to fly fast and often found standing on the ground or leaves to get sunlight. Several studies reported finding this species standing on the ground or damp stones searching for minerals. This species was abundantly found in the study since it is part of the family Nymphalidae and has polyfag characteristic. Polyfag butterflies could multiply on many types of plants. Their larvae could survive in low diversity of host 
plants (Helmann, 2002). The high existence of a butterfly species is supported by the availability of plants as sources of food (Yamamoto et al., 2007).

The existence of butterflies in a habitat highly depends on the condition of the habitat and the availability of sources of nectar as well as host plants. Several species of butterflies were found in low frequency and limited only to a type of habitat. Species of butterflies that were found in low frequency with limited distribution are those that are sensitive to the damage of the habitat (Sunduvu and Dumbuya, 2008). Damage to the habitat causes fragmentation and extinction of plants as sources of nectars and host to those butterflies (Hardy et al., 2007).

Species abundance, species richness index, species diversity index, and species evenness index were found to be the highest in the forest edge habitat since this habitat has a variety of plants that can act as a food source as well as host plants for the butterflies. The high species diversity of butterflies in the forest edge habitat could also be due to the existence of a river in the area that can support the life of the butterflies. Butterflies need minerals to survive, which are usually gained from the soil surface, rocks, or riverbank. Riverbank has a variety of vegetations, rocks, sand, mud, and water that attract more butterflies to get water and nutrient from wet rocks, sand, and mud along the riverbank (Van Vu and Quang Vu, 2011).

There was low diversity of butterflies in the bushes habitat since the habitat has a low number of flowery plants and mostly contains grass (Poaceae) and ferns (Pteridophyta). The bushes habitat was originally forest that was converted into farm area. When the farm was abandoned, it turned into bushes. The low species diversity index shows the low availability of food sources and adaptability of the butterflies towards limited environmental factors. Conversion of the forest into farms could reduce natural biodiversity. Several studies have shown that conversion of the natural habitat is the cause of the decline of butterfly species (Chowdhury et al., 2017). Species diversity could decline due to fragmentation of the habitat (Bayero, 1995).

A decrease in species diversity of butterflies was also reported due to deforestation in Kalimantan (Schulze and Fielder, 1998) and in Sulawesi (Fermont et al., 2005). Change of habitat due to change of function of parts of the forest could be a serious threat to the existence of specific species of butterflies in Indonesia. There is a correlation between the diversity of butterflies and their habitat. Larvae and adult butterflies depend on the diversity of host plants. Although butterflies could migrate to new areas, if the plant food is extinct, thus the butterflies also go to extinction. Hamer and Hill (2000) conducted a study on butterfly community in tropical areas and reported that abundance and diversity of butterfly species were higher in forests that have not been used for logging yet compared to forests with logging activity. Their study showed that damage to the forest highly affects species diversity of butterflies. The diversity of butterflies increases when the scale of the habitat and the complexity of the vegetation structure increase (Nkongolo and Bapeamon, 2018). Sharma and Joshi (2009) reported that there was a correlation between the complexity of the habitat structure, shape of vegetation, and diversity of butterflies. High vegetation diversity will increase the diversity of butterflies. The environmental support system such as the availability of habitat, water, mineral, food, temperature, and humidity affect the diversity of butterflies (Mas'ud et al., 2018).

Species evenness index was found the highest at the forest edge habitat. High evenness index shows the lack of dominant species of butterflies. The smaller the 
species evenness index, thus the less equal the species distribution is and there is at domination by certain species of butterfly (Magurran, 1988).

Species richness index and species diversity index of butterflies were found to be positively correlated with humidity and vegetative canopy, but negatively correlated with the air temperature. Temperature highly affects the activity of butterflies, their distribution, growth, and breeding. The temperature at the bushes habitat was higher than the forest edge habitat and the farm area. High air temperature causes a decrease of the volume of nectar secretion in flowers (Efendi, 2009), thus butterflies reduce their activity in the area and move to the forest area that is warm in order to save their energy and reduce evaporation of moisture from their body. This phenomenon causes low species diversity and number of individuals of butterflies found in the bushes habitat.

Rajagopal et al. (2011) reported that species richness index of butterflies is affected by air temperature and humidity. Moreover, Kunte (2001) and Pandhye et al. (2006) also reported that temperature and rainfall are two important factors that directly affect richness and population of butterflies. Tree canopy highly affects the diversity of butterfly species since they can provide protection and food source for the butterflies. There are several species of butterflies that live in a habitat with thick forest canopy, but on the other hand, there are also species that live in a habitat with less forest canopy.

Species similarity among habitats could be measured with similarity index or species similarity coefficient. Similarity index is also used as a basis for cluster analysis. The highest similarity index was found between the forest edge and farm habitats. This shows that there is a high similarity of butterfly species found in the forest edge and in the farming area. This phenomenon could be due to the fast movement of butterflies from one habitat to another and the variety of vegetation in habitats, thus affecting the existence of butterflies. Kendeigh (1980) reported factors that cause similarity of species between two habitats to include a short distance between the two habitats, a similar composition of vegetation, and others.

\section{Conclusions}

Butterfly species found in Sangihe Island consisted of 5 families, 39 species, and 944 individuals. Nymphalidae is the most abundant family with the highest number of species when compared to other families, since the family can adapt well to the environmental condition, has the most number of family members, and tend to be polyfag. The polyfag characteristic allows the Nymphalidae to fulfill its need for host plan although the host plant is not available. Based on the type of habitat, the highest species richness index, species diversity index, and species evenness index were found in the forest edge habitat, while the lowest ones were found in the bushes habitat. The difference in the diversity of butterflies among habitats was due to the different structure and complexity of the vegetation in each habitat. High vegetation diversity will increase the diversity of butterflies. Availability of resources such as habitat, water, mineral, food, temperature, and humidity affect the diversity of butterflies. Meanwhile, environmental factors such as temperature and humidity highly affect the activities, distribution, growth, and breeding of butterflies. The temperature at the bushes habitat was higher than the other two habitats. Therefore, the volume of nectar secretion in flowers decreases, so the butterflies reduce their activities in the area or move to the warm forest edge area. 
Based on the results of this study, it is recommended to conduct further research on plant species which have an ecological role and function as food sources and hosts for butterflies. The time period of research might be also extended so that the research can be conducted during the rainy season as well. The use of herbicide to kill grasses and weeds should be carefully monitored because it can kill butterflies too. Agroforestry system can be implemented in forest areas to increase vegetation diversity, and consequently to add more host plants and food sources for butterflies.

Acknowledgements. The authors would like to thank the Directorate of Research and Community Service and Directorate of Research and Development, the Ministry of Research, Technology, and Higher Education, for their financial support for the research through Competency-based Research 2018.

\section{REFERENCES}

[1] Alarape, A, A., Omifolaji, J. K., Mwansat, G. S. (2015): Butterfly species diversity and abundance in University of Ibadan Botanical Garden, Nigeria. - Open J. of Ecology 5: 352-360.

[2] Amir, M., Kahono, S. (2008): Butterflies (Lepidoptera). - In: Amir, M., Kahono, S. (eds.) Insects in Halimun Mountain National Park West Region. JICA, Jakarta.

[3] Amir, M., Noerdjito, W. A., Kahono, K. (2003): Butterfly (Lepidoptera). - In: Amir, M., Kahono, S. (eds.) Insects in Halimun Mountain National Park West Region. - JICA, Jakarta.

[4] Arya, M. K., Dayakrishnan, Chaudhary, R. (2014): Species richness and diversity of butterflies in and around Kumaun University, Nainital, Uttarakhand, India. - J. of Entomology and Zoology. Studies 2(3): 153-159.

[5] Axmacher, J. C., Tunte, H., Schrumpf, M., Mullerhohenstein, K., Layaruu, H. V. M., Fiedler, K. (2004): Diverging diversity pattern of vascular plants and geometrid moth during forest regeneration on Mt. Kilimanjaro, Tanzania. - J. Biogeo. 31: 895-904.

[6] Bayero, Y. G. (1995): The effects of forest fragmentation on butterfly communities in Central Spain. - J. of Bioge. 22(1): 129-140. DOI: 10.2307/2846077.

[7] Bora, A., Meitei, L. R. (2014): Diversity of butterflies (Order: Lepidoptera) in Assam University Campus and its Vicinity, Cachar District, Assam, India. - J. Biodiv. Env. Sci. 5(3): 328-339.

[8] Braby, M. F. (2004): The Complete Field Guide to Butterflies of Australia. - CSIRO Publishing, Collinwood.

[9] Castro, A., Espinosa, C. I. (2015): Seasonal Diversity of Butterflies and Its Relationship with Woody-Plant Resource Availability in an Ecuadorian Tropical Dry Forest. Departamento de Ciencias Naturales Universidad Tecnica Particular de Loja, Ecuador.

[10] Central Agency on Statistics (2015): Siau Tagulandang Biaro Islands in statistics 2015. Central Agency on Statistics, Districts Siau, Tagulandang, Biaro Island, North Sulawesi.

[11] Chowdhury, S., Hesselberg, T., Böhm, M., Islam, M. R., Aich, U. (2017): Butterfly diversity in a tropical urban habitat (Lepidoptera: Papilionoidea). - Oriental Insects 51(4): 417-430. DOI: 10.1080/00305316.2017.1314230.

[12] Coote, L. D. (2000): CITES Identification Guide Butterflies. - Minister of Environment, Canada.

[13] Efendi, M. A. (2009): Diversity of butterflies (Lepidoptera: Ditrysia) in "Corridor Forest", Gunung Halimun-Salak National Park, West Java. - Tesis, School of Post Graduate Studies of Bogor Agricultural University, Bogor.

[14] Fermon, H., Waltert, M., Larsen, T. B., Dall'Asta, U., Muhlenberg, M. (2005): Forest use and vertical stratification in fruit feeding butterflies of Sulawesi, Indonesia: impacts for conservation. - Biodiversity and Conservation 14(2): 333-350. 
[15] Ghosh, A., Mukherjee, T. (2016): Butterfly diversity at suburban green patch: a sustainable approach toward conservation. - Journal of Entomology and Zoology Studies 4(2): 34-19.

[16] Hamer, K. C., Hill, J. K. (2000): Scale-dependent effects of habitat disturbance on species richness in tropical forests. - Conserv. Biol. 14: 1435-1440.

[17] Hamer, K. C., Hill, J. K., Benedick, S., Mustaffa, N., Sherratt, T. N., Maryati, M., Chey, V. K. (2003): Ecology of butterflies in natural and selectively logged forests of Northern Borneo: The importance of habitat heterogeneity. - Journal of Applied Ecology (40): 150-162.

[18] Hammer, O., Harper, D. A. T., Ryan, PD. (2001): PAST: Paleontological Statistics Software Package for Education and Data Analysis. - Palaeontologia Electronica 4(1): 19.

[19] Hardy, P. B., Sparks, T. H., Isaac, N. J. B., Dennis, R. L. H. (2007): Specialism for larvae and adult consumer resources among British butterflies: implication for conservation. Biol Conserv. 138: 440-452.

[20] Haroon, Ahmad, T., Ahsan, A., Ahmad, I. (2013): Diversity pattern of butterfly Lepidoptera (Papilio damoleus) in Union Council Koaz Bahram, Khyber Pakhtunkhwa, Pakistan. - Journal of Science: Basic Applied Research 9(1): 94-99.

[21] Helmann, J. J. (2002): The effect of an environmental change on mobile butterfly larvae and the nutritional quality of their hosts. - J Anim Ecology 71: 925-936.

[22] Jumar (2000): Agricultural Entomology. - Rineka Cipta, Jakarta, Indonesia.

[23] Kendeigh, S. C. (1980): Ecology with Special Reference to Animal and Man. Department of Zoological University of Illinois at Urbana-Champaign. Prentice-Hall of India Private Limited, New Delhi.

[24] Koneri, R., Maabuat, P. V. (2016): Diversity of butterflies (Lepidoptera) in ManemboNembo Wildlife Reserve, North Sulawesi. - Pakistan Journal of Biological Sciences 19(5): 202-210.

[25] Koneri, R., Saroyo, S. (2012): Diversity and distribution of butterflies (Lepidoptera) in Manado Tua Mount, Sea National Park Bunaken, North Sulawesi. - Jurnal Bumi Lestari 12(2): 357-365.

[26] Krebs, C. J. (1999): Ecological Methodology. Second Ed. - Addison-Wesley, Menlo Park.

[27] Kunte, K. (2001): Butterfly diversity of Pune city along the human impact gradient. Journal of Ecological Society 13(14): 40-45.

[28] Lewis, T. O. (2001): Effect of experimental selective logging on tropical butterflies. Conservation Biology 15(2): 389-400.

[29] Lamatoa, D. C., Koneri, R., Siahaan, R., Maabuat, P. C. (2013): Population of butterflies (Lepidoptera) in Mantheage Island, Orth Sulawesi. - Jurnal Ilmiah Sains 13(1): 52-56.

[30] Ludwig, J. A., Reynolds (1988): Statistical Ecology; a Primer on Methods and Computing. - John Wiley and Sons, New York.

[31] Magurran, A. E. (1988): Ecological Diversity and Its Measurements. - Croom Helm Limited, London.

[32] Mas'ud, A., Corebima, A. D., Amin, M., Rohman, F. (2018): RAPD-based molecular analysis genetic diversity of Ornithoptera Croesus found in Bacan Island, Indonesia. Biodiversitas 19(4): 1273-1279. DOI: 10.13057/biodiv/d190413.

[33] Nidup, T., Dorji, T., Tshering, U. (2014): Taxon diversity of butterflies in different habitat types in Royal Manas National Park. - Journal of Entomology and Zoology Studies, 2(6): 292-298.

[34] Nkongolo, N. V., Bapeamoni, F. (2018): The effect of land use type on butterfly diversity at Masako Forest Reserve, Kisangani, Democratic Republic of Congo. - International Journal of Biodiversity and Conservation 10(3): 131-144. DOI: 10.5897/IJBC2017.1160. 
[35] Ohsawa, M. (2005): Species richness and composition of Curculionidae (Coleoptera) in a conifer plantation, secondary forest, and old-growth forest in the central mountainous region of Japan. - Ecology Research 20: 632-645.

[36] Pandhye, A. D., Dahanukar, N., Paingankar, M., Deshpande, D. (2006): Season and landscape wise of butterflies in Tamhini, Northern Western Ghats, India. - Zoo's Print Journal 21(3): 2175-2181.

[37] Panjaitan, R. (2008): Distribution of butterflies (Superfamily Papilionoidae: Lepidoptera) in Minyambou, Manokwari Arfak mountains nature reserve, West Papua. Berk. - Ilm. Biol 7: 11-16.

[38] Parmesan, C., Yohe, G. (2003): A globally coherent fingerprint of climate change impacts across natural systems. - Nature 421: 37-42.

[39] Patil, K. G., Shende, V. A. (2014): Butterfly diversity of Gorewada International BioPark, Nagpur, Central India. - Arthropods 3: 111-119

[40] Patil, K. G., Kanekar, A., Shende, A.V., Bhimrao, U.S. (2017): A report on butterfly diversity of Rawanwadi Reservoir, Bhandara (Maharashtra), India. - Arthropods: 6: 2128

[41] Peggie, D. (2014): Butterflies. - Pandu Aksara Publishing, Jakarta, Indonesia.

[42] Peggie, D., Amir, M. (2006): Practical Guide to the Butterflies of Bogor Botanic Garden. - Pusat Penelitian biologi, LIPI, Cibinong, Indonesia.

[43] Perveen, F. K., Haroon (2015): Checklist of butterfly (Insecta: Lepidoptera) fauna of Tehsil Tangi, Khyber Pakhtunkhwa, Pakistan. - Arthropods 4: 98-106.

[44] Plona, M. B. (2002): Butterfly Monitoring Report. - Cuyahoga Valley National. http://www.nps.gov/cuva/management/rm/02butterflies.htm.

[45] Rajagopal, T., Sekar, M., Manimozhi, A., Baskar, N., Archunan, G. (2011): Diversity and community structure of butterfly of Arignar Anna Zoological Park, Chennai, Tamilnadu. - Journal of Environmental Biology 32: 201-207.

[46] Rizal, S. (2007): Population butterfly in Rimbo Panti Nature Reserve and Kawasan Wisata Lubuk Minturun West Sumatera. - Mandiri 9: 177-184.

[47] Rosmidi, F. H., Zahidin, M. A., Adanan, A., Azizah, A., Pesiu, E., Abdullah, M. T. (2017): Checklist of butterflies in Pulau Perhentian and Pulau Bidong, Terengganu. Journal of Sustainability Science and Management 12(1): 40-48.

[48] Sari, E. F. W., Soekardi, H., Nukmal, N., Martinus (2013): Diversity of Nymphalidae in Tegal Island and Puhawang Kecil Island, Lampung Bay. - Conference Paper: Seminar Nasional Sains and Teknologi V Lembaga Penelitian Universitas Lampung, Bandar Lampung.

[49] Sarma, K., Kumar, A., Devi, A., Mazumdar, K., Krishna, M., Mudoi, P., Das, N. (2012): Diversity and habitat association of butterfly species in Foothills of Itanagar, Arunchal Paradesh, India. - Zoology 1: 67-77.

[50] Schulze, C. H., Fiedler, K. (1998): Habitat preferences and flight activity of Morphinae butterflies in a Bornean rain forest, with a note on sound production by adult Zeuxidia (Lepidoptera: Nymphalidae). - Malay Biol 8: 800-809.

[51] Shahabuddin, Schulze, C. H., Tscharnke, T. (2005): Changes of dung beetle communities from rainforests towards agroforestry systems an annual cultures in Sulawesi (Indonesia). - Biodiversity and Conservation 14: 863-877.

[52] Sharma, G., Joshi, P. G. (2009): Diversity of butterflies (Lepidoptera: Insecta) from Dholbaha dam (Distt. Hoshiarpur) in Punjab Shivalik, India. - Biological Forum an International Journal 1(2): 11-14.

[53] Shekelle, M., Groves, C., Merker, S., Supriatna, J. (2008): Tarsius tumpara: A new tarsier species from Siau Island, North Sulawesi. - Primate Conservation 23: 55-64.

[54] StatSoft. (2001): Stastistics for windows, 6.0. - Statsoft Inc. Tulsa, Oklahoma.

[55] Sumarto, S., Siahaan, P. (2012): Biogeografi. - Penerbit Alfabeta, Bandung.

[56] Sunduvu, A. J., Dumbuya, R. (2008): Habitat preferences of butterflies in the Bumbuna forest, Northern Sierra Leone. - J Ins. Sci 8: 1-17. 
[57] Tallei, T. E., Nangoy, M. J., Koneri, R., Saroyo, S. (2015): Biodiversity assessment of Mt. Tumpa Forest Park, North Sulawesi, Indonesia. - Asian Journal Biodiversity 6(2): 121.

[58] Tsukada, E., Nishiyama, Y. (1981): Butterflies of the South East Asian Island, Part II Pieridae-Danaidae. - Palapa Co. Ltd., Minatok-Tokyo.

[59] Tsukada, E., Nishiyama, Y. (1982): Butterflies of the South East Asian Island, Part I Papilionidae. - Palapa Co. Ltd., Minatok-Tokyo.

[60] Tsukada, E., Nishiyama, Y. (1982): Butterflies of the South East Asian Island, Part III Satyridae-Lybytheidae. - Palapa Co. Ltd., Minatok-Tokyo.

[61] Tsukada, E., Nishiyama, Y. (1985): Butterflies of the South East Asian Island, Part IV Nympalidae (I). - Palapa Co. Ltd., Minatok-Tokyo.

[62] Tsukada, E., Nishiyama, Y. (1991): Butterflies of the South East Asian Island, Part V Nympalidae (II). - Palapa Co. Ltd., Minatok-Tokyo.

[63] Van Vu, L., Quang Vu., C. (2011): Diversity pattern of butterfly communities (Lepidoptera, Papilionoidae) in different habitat types in a Tropical Rain Forest of Southern Vietnam. - ISRN Zoology 2011: 1-8. DOI: 10.5402/2011/818545.

[64] Vane-Wright, R. I, de Jong, R. (2003): The butterflies of Sulawesi: annotated checklist for a critical island fauna. - Zool. Verh. Leiden 343: 3-267.

[65] Vu, V. L. T. C., Bonebrake, M. Q., Vu, N. T. N. (2015): Butterfly diversity and habitat variation in a disturbed forest in Northern Vietnam: - Pan-Pacific Entomologist 91(1): 29-38.

[66] Widhiono, I. (2015): Diversity of butterflies in four different forest types in Mount Slamet, Central Java, Indonesia. - Biodiversitas 16(2): 196-204.

[67] Yamamoto, N., Yokoyama, J., Kawata, M. (2007): Relative resource abundance explains butterfly biodiversity in island communities. - The National Academy of Sciences 104(25): 10524-10529. 